concentrations, ${ }^{16}{ }^{17}$ which may be due to the inhibition of aldehyde dehydrogenase by chlorpropamide ${ }^{1 *}$; furthermore, it has been suggested that in vitro met-enkephalin can combine rapidly with acetaldehyde to form a stable adduct which changes its opiate biological activity considerably. ${ }^{19}$ If this were true in vivo possibly the acetaldehyde-enkephalin complex might change the half life of met-enkephalin, which might result in an increased plasma concentration after alcohol ingestion. The formation of such an adduct might change certain biological properties of met-enkephalin, leading to the production of a facial flush.

The origin of circulating met-enkephalin in man is not clear. It may derive partly from the adrenal medulla, where high concentrations are known to exist, or from the gut or neural plexuses, where it is believed to subserve a role as a neurotransmitter or neuromodulator. It is of interest, therefore, that this is the first experimental manoeuvre which has been shown significantly to change circulating immunoreactive met-enkephalin which occur in response to some interaction between chlorpropamide (or its metabolite) and alcohol appear, however, to be independent of the ability to flush or the presence of diabetes.

Dr S Medbak is supported by the University of Basrah, Basrah, Iraq. Dr V Clement-Jones is an MRC training fellow. We also thank the Joint Research Board of St Bartholomew's Hospital for support.

Requests for reprints should be addressed to Professor Lesley Rees, Department of Chemical Endocrinology, St Bartholomew's Hospital, 51-53 Bartholomew Close, London EC1A 7BE.

\section{References}

${ }^{1}$ Leslie RDG, Pyke DA. Chlorpropamide-alcohol flushing: a dominantly inherited trait associated with diabetes. $\mathrm{Br} M e d \mathcal{F}$ 1978; ii:1519-21.

2 Pyke DA, Leslie RDG. Chlorpropamide-alcohol flushing: a definition of its relation to non-insulin dependent diabetes. Br Med F 1978;ii:1521-2.
${ }^{3}$ Leslie RDG, Barnett AH, Pyke DA. Chlorpropamide alcohol flushing and diabetic retinopathy. Lancet 1979 ; : $: 997-9$.

Barnett AH, Pyke DA. Chlorpropamide alcohol flushing and large-vessel disease in non-insulin dependent diabetes. $\mathrm{Br}$ Med $\mathcal{f} 1980 ; 281: 261-2$.

${ }^{5}$ De Silva NE, Tunbridge WMG, Alberti KGMM. Low incidence of chlorpropamide-alcohol flushing in diet-treated, non-insulin dependent diabetes. Lancet 1981 ; i:128-31.

${ }^{6}$ Kobberling J, Bengsch N, Brüggeboes B, Schwarck H, Tillil H, Weber M. The chlorpropamide alcohol flush. Lack of specificity for familial noninsulin dependent diabetes. Diabetologia 1980;19:359-63.

${ }^{7}$ De Silva NE, Tunbridge WMG. Chlorpropamide alcohol flushing (CPAF) in non-insulin dependent diabetes (NIDDs). Diabetologia $1980 ; 19: 269$.

${ }^{8}$ Strakosch CR, Jeffreys DB, Keen H. Blockade of chlorpropamide alcohol flush by aspirin. Lancet $1980 ; \mathrm{i}: 394-6$.

${ }^{9}$ Barnett AH, Spiliopoulos AJ, Pyke DA. Blockade of chlorpropamidealcohol flushing by indomethacin suggests an association between prostaglandins and diabetic vascular complications. Lancet 1980;ii: 164-6.

${ }^{10}$ Leslie RDG, Pyke DA, Stubbs WA. Sensitivity to enkephalin as a cause of non-insulin dependent diabetes. Lancet 1979 ; : $341-3$.

11 Jeffreys DB, Strakosch CR, Keen H. Facial flushing in diabetes. Lancet $1979 ;$ ii $: 1195$.

12 Clement-Jones V, Lowry PJ, Rees LH, Besser GM. Met-enkephalin circulates in human plasma. Nature 1980;183:295-7.

13 McLoughlin L, Lowry PJ, Ratter S, Besser GM, Rees LH. $\beta$-endorphin and $\beta-M S H$ in human plasma. Clin Endocrinol 1980;12:287-92.

${ }^{14}$ Clement-Jones V, Lowry PJ, Rees LH, Besser GM. Development of a specific extracted radioimmunoassay for methionine enkephalin in human plasma and cerebrospinal fluid. F Endocrinol 1980;86:231-43.

15 Jeffcoate WJ, Rees LH, Lowry PJ, Hope J, Besser GM. $\beta$-endorphin in human cerebrospinal fluid. Lancet 1978;ii:119-21.

${ }^{16}$ Jerntorp $\mathrm{P}$, Ohlin $\mathrm{H}$, Bergaström B, Almér LO. Elevation of plasma acetaldehyde-the first metabolic step in CPAF ? Diabetologia 1980;19: 286.

17 Pyke DA, Barnett AH, Gonzelez-Auvert C, Dickenson CJ, Saunders JB, Williams R. Blood acetaldehyde levels during CPAF testing in "flushers" and "non-flushers." Diabetologia $1981 ; 20: 12$.

18 Podgainy H, Bressler R. Biochemical basis of the sulphonylurea-induced antabuse syndrome. Diabetes 1968;17:679-83.

19 Lightman SL, Summers MC. Alterations in the activities of endogenous opiates by a metabolite of alcohol. $\mathcal{F}$ Endocrinol 1980;87:38-9.

(Accepted 7 August 1981)

\title{
Blood concentrations of acetaldehyde during chlorpropamide-alcohol flush
}

\author{
A H BARNETT, C GONZALEZ-AUVERT, D A PYKE, J B SAUNDERS, R WILLIAMS, \\ C J DICKENSON, M D RAWLINS
}

\begin{abstract}
To test the suggestion that chlorpropamide-alcohol flushing (CPAF) resembles the disulfiram effect and might be mediated by acetaldehyde, the initial metabolite of alcohol, blood concentrations of acetaldehyde were measured after a drink of alcohol in controls and diabetics positive and negative for CPAF. The CPAFpositive diabetics had significantly greater blood acetaldehyde concentrations after alcohol than the CPAFnegative diabetics both with a single dose of chlorpropamide and after two weeks' chlorpropamide treatment. Concentrations in the CPAF-positive group after chlorpropamide were also significantly greater than after a placebo tablet. There was also a clear separation in the increase in facial temperature after two weeks of chlorpropamide between the CPAF-positive and CPAFnegative groups (although there was some overlap after a single tablet). There was no difference in plasma chlorpropamide or alcohol concentrations between CPAFpositive and CPAF-negative diabetics.
\end{abstract}

These findings show that CPAF is distinct from alcohol flushing and that the acetaldehyde concentration in the blood provides an objective measure of CPAF. The difference between flushing and non-flushing diabetics cannot be accounted for by differences in blood concentrations of chlorpropamide or alcohol.

\section{Introduction}

Many non-insulin-dependent diabetics treated with chlorpropamide show facial flushing after taking a small quantity of alcohol-chlorpropamide-alcohol flushing (CPAF). ${ }^{12}$ We have previously suggested that CPAF is inherited ${ }^{2} 3$ and that it may provide clues to the causes of non-insulin-dependent diabetes. ${ }^{4}$

In 1962 FitzGerald et al suggested that CPAF might be a disulfiram-like reaction mediated by acetaldehyde, the intermediate metabolite of alcohol. ${ }^{1}$ Using the relatively insensitive methods of those days they found no significant difference in acetaldehyde concentrations in CPAF-positive and CPAFnegative diabetics. Recently a sensitive and precise method for 
assaying of acetaldehyde has been described using head-space gas chromatography. ${ }^{5}$ Jerntorp et al have reported that during CPAF testing flushers show much higher acetaldehyde concentrations than non-flushers-indeed that there is a clear separation between the two groups. ${ }^{6}$ It has also been suggested that CPAF-positive subjects (flushers) have higher concentrations of chlorpropamide than those who are CPAF negative (nonflushers). ${ }^{7}$

We measured blood concentrations of acetaldehyde during CPAF testing in controls and diabetics positive and negative for CPAF after (a) placebo, (b) a single tablet of chlorpropamide, and $(c)$ two weeks' chlorpropamide treatment. We also measured chlorpropamide and alcohol concentrations.

\section{Patients and methods}

Twenty-one non-insulin-dependent diabetics-11 CPAF positive (flushers) and $10 \mathrm{CPAF}$ negative (non-flushers)-and 10 non-diabetics were studied. CPAF status in the diabetics had been assessed subjectively as previously described before the study started. ${ }^{2}$ None had taken chlorpropamide for at least three weeks.

The mean $( \pm S E M)$ ages $(59 \pm 3,64 \pm 2$ respectively) and duration of diabetes $(10 \pm 2,10 \pm 2$ years) were similar in the diabetics positive and negative for CPAF. The mean age of the controls was less $(46+3)$. There were eight men and three women in the CPAF-positive group and seven men and three women in the CPAF-negative group.

On day 1, after an overnight fast, blood was taken for liver function tests, and $250 \mathrm{mg}$ chlorpropamide was then given by mouth. After 11 hours a temperature probe was connected to each subject $2 \mathrm{~cm}$ below the outer canthus of the eye. After at least 45 minutes' stabilisation duplicate samples of blood were taken for measuring acetaldehyde and alcohol concentrations; $9 \mathrm{ml}$ of $90 \%$ alcohol in orange juice was then given and facial temperature was recorded for a further 40 minutes. Blood acetaldehyde and alcohol concentrations were again measured in duplicate 25 minutes after the alcohol challenge. Blood was also taken at $0,3,6,9,12,24,48,72$, and 96 hours for measuring plasma chlorpropamide concentrations.

On day 5 the CPAF-positive diabetics were started on a two-week course of either placebo or chlorpropamide $250 \mathrm{mg}$ daily in a randomised single-blind fashion, and after a further two weeks off treatment they were switched to the other drug. At the end of each period the alcohol challenge test was repeated as on day 1 . The CPAF-negative diabetics had a two-week course of chlorpropamide but not placebo. The controls had a placebo test but did not receive the two-week course of chlorpropamide because of the risk of hypoglycaemia.

Plasma chlorpropamide was measured by gas-liquid chromatography. ${ }^{8}$

Blood alcohol and acetaldehyde concentrations were measured by head-space gas chromatography. Samples were prepared for assay of acetaldehyde by the method of von Wartburg and Ris. ${ }^{5}$ After incubation at $60^{\circ} \mathrm{C}$ for 30 minutes $1 \mathrm{ml}$ of head space was injected on to a capillary column $100 \mathrm{~m} \times 0.7 \mathrm{~mm}$ coated with Carbowax 400 and maintained at a temperature of $55^{\circ} \mathrm{C}$; the carrier gas was nitrogen and the flow rate $20 \mathrm{ml} / \mathrm{min}$. Alcohol and acetaldehyde were measured by a flame ionisation detector by calculating the ratio of their peak heights to that of the n-propanol internal standard, and using calibration

Diabetic Department, King's College Hospital, London SE5 9RS

A H BARNETT, MD, MRCP, research registrar

C GONZALEZ-AUVERT, MD, honorary visiting consultant

D A PYKE, MD, FRCP, consultant physician

Liver Unit, King's College Hospital, London SE5 9RS

J B SAUNDERS, MRCP, lecturer

R WILLIAMS, MD, FRCP, director

Process Research Department, Allied Breweries (UK) Ltd,

Burton-on-Trent DE14 1BZ

C J DICKENSON, PHD, principal research scientist

Department of Pharmacological Sciences, The University, Newcastle upon Tyne NE1 7RU

M D RAWLINS, MD, FRCP, professor of clinical pharmacology curves prepared by adding ethanol or acetaldehyde to a precipitated plasma suspension.

The coefficient of variation of the acetaldehyde assay for replicate aqueous standards at a concentration range of 1.1-23 $\mu \mathrm{mol} / 1$ (0.05-1 $\mathrm{mg} / \mathrm{l})$ was $7 \%$. The coefficient of variation for 90 duplicate blood samples, which had a mean acetaldehyde concentration in a diluted plasma suspension of $2 \cdot 3 \mu \mathrm{mol} / 1(0.1 \mathrm{mg} / \mathrm{l})$, was $17 \%$.

All results are expressed as means $\pm S E M$ and were compared using the Wilcoxon $U$ test for unpaired data.

\section{Results}

All subjects had normal liver function values (including $\gamma$-glutamyl transferase, alkaline phosphatase, and aspartate aminotransferase).

\section{Acetaldehyde levels}

Before alcohol challenge blood acetaldehyde concentrations were undetectable $(<1.1 \mu \mathrm{mol} / 1(0.05 \mathrm{mg} / \mathrm{l}))$ in all subjects. After alcohol the results were as follows (fig 1 ).

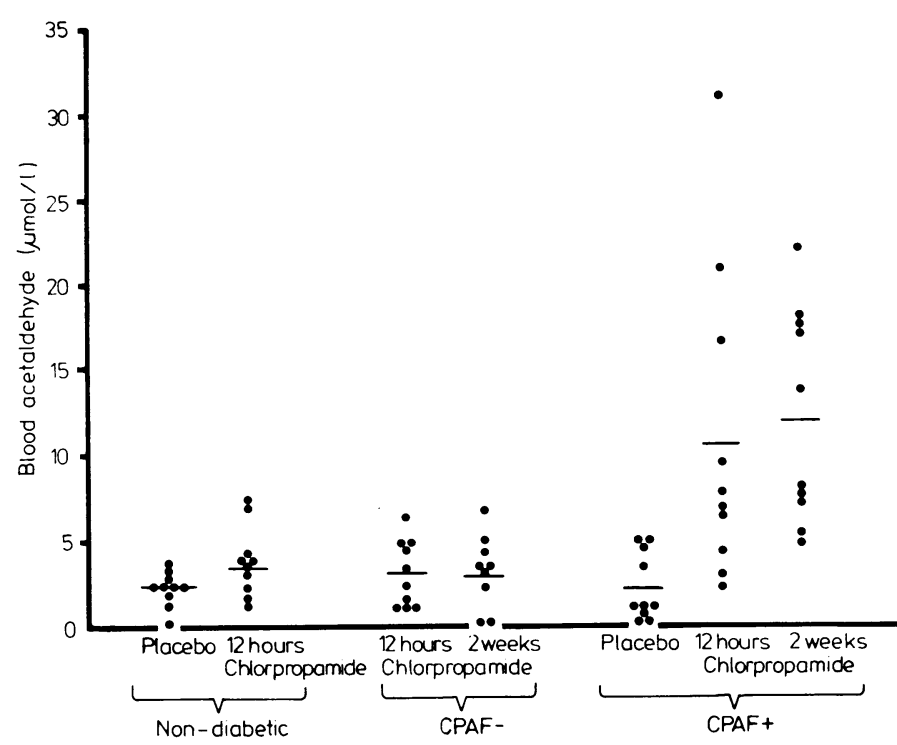

FIG 1-Blood acetaldehyde concentration in CPAF-positive and CPAFnegative diabetics and controls 25 minutes after alcohol $(a)$ with placebo, $(b)$ with chlorpropamide $250 \mathrm{mg}$ given 12 hours before, and $(c)$ after two weeks' treatment with chlorpropamide.

Conversion: SI to traditional units-Acetaldehyde: $1 \mu \mathrm{mol} / 1 \approx 0.044 \mathrm{mg} / \mathrm{l}$.

After placebo-The CPAF-positive group had acetaldehyde concentrations $(2 \cdot 3 \pm 0 \cdot 7 \mu \mathrm{mol} / \mathrm{l}(0 \cdot 10 \pm 0.03 \mathrm{mg} / \mathrm{l}) \mathrm{n}=10)$ similar to those of the non-diabetic controls $(2.5 \pm 0.5 \mu \mathrm{mol} / \mathrm{l}(0.11 \pm 0.02 \mathrm{mg} / \mathrm{l}))$.

After one day's chlorpropamide-The flushers showed a significantly higher concentration of acetaldehyde $(10 \cdot 4 \pm 2 \cdot 9 \mu \mathrm{mol} / 1(0 \cdot 46 \pm 0 \cdot 13$ $\mathrm{mg} / \mathrm{l}), \mathrm{n}=10$ ) after a single tablet of chlorpropamide than they had shown after the placebo tablet $(\mathrm{p}<0.01)$ and than that shown by the non-flushers $(3.2 \pm 0.7 \mu \mathrm{mol} / 1(0.14 \pm 0.03 \mathrm{mg} / \mathrm{l}) ; \mathrm{p}<0.02)$ and the controls $(3.9 \pm 0.7 \mu \mathrm{mol} / 1(0.17 \pm 0.03 \mathrm{mg} / \mathrm{l}) \mathrm{p}<0.02)$.

After two weeks' chlorpropamide-The CPAF-positive group showed a higher blood acetaldehyde value $(11.8 \pm 2.0 \mu \mathrm{mol} / 1 \quad(0.52 \pm 0.09$ $\mathrm{mg} / \mathrm{l}), \mathrm{n}=10$ ) after two weeks' chlorpropamide than after a single tablet, and this was significantly greater than the value in the CPAFnegative group $(2.9 \pm 0.7 \mu \mathrm{mol} / \mathrm{l}(0.13 \pm 0.03 \mathrm{mg} / \mathrm{l}), \mathrm{n}=9 ; \mathrm{p}<0.01)$.

\section{Facial temperature}

After a single tablet of chlorpropamide the mean increase in facial temperature was greater in the CPAF-positive subjects than in the CPAF-negative subjects $\left(1 \cdot 6 \pm 0 \cdot 2 v 0 \cdot 6 \pm 0 \cdot 1^{\circ} \mathrm{C}\right.$ respectively; $\left.\mathrm{p}<0.01\right)$, but there was some overlap between them (fig 2). After two weeks' chlorpropamide treatment there was no difference in the temperature rise in the CPAF-negative cases $\left(0 \cdot 6 \pm 0 \cdot 1^{\circ} \mathrm{C}, \mathrm{n}=9\right)$, but the mean in 
the CPAF-positive group rose to $2 \cdot 3: 0 \cdot 3 \mathrm{C}$. Furthermore, there was no overlap between the two groups: no CPAF-negative case exceeded $1^{\prime} \mathrm{C}$ and none of the CPAF-positive cases showed a rise of less than $1 \cdot 4^{\circ} \mathrm{C}$.

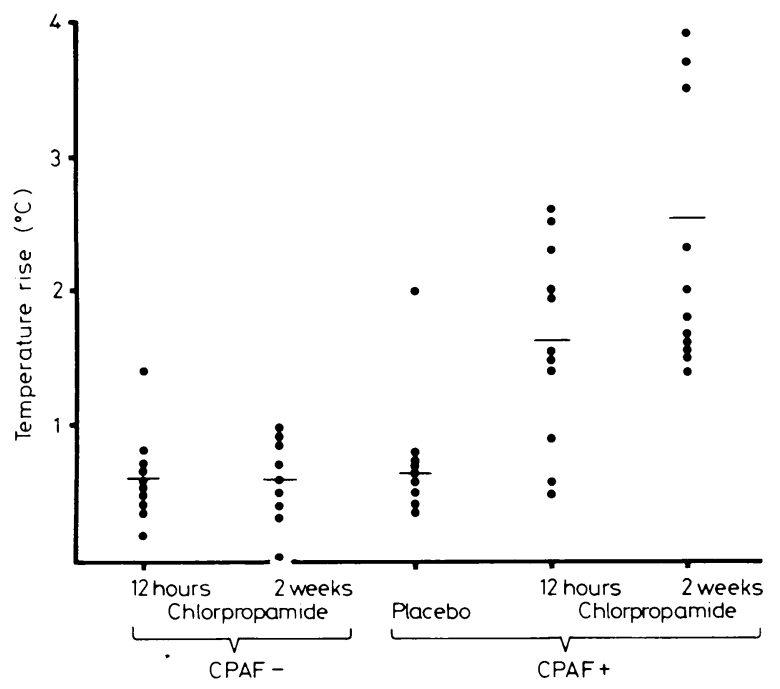

FIG 2-Increase in tempcrature in CPAF-positive and CPAFnegative diabetics after alcohol (a) with placebo, (b) with chlorpropamide $250 \mathrm{mg}$ given 12 hours before, and (c) after two weeks' treatment with chlorpropamide.

\section{Chlorpropamide concentrations}

There was no difference in chlorpropamide concentration at any time between the two groups of diabetics after a single tablet or after two weeks of chlorpropamide treatment: mean plasma chlorpropamide concentrations in CPAF-positive and CPAF-negative groups at 12 hours were $58.9 \pm 8.7 \mu \mathrm{mol} / \mathrm{l}(16.3 \pm 2.4)$ and $61.8 \pm 9.0 \mu \mathrm{mol} / 1$ $(17 \cdot 1+2 \cdot 5 \mathrm{mg} / \mathrm{l})$ respectively) and at two weeks $331 \pm 38 \cdot 7 \mu \mathrm{mol} / \mathrm{l}$ $(91 \cdot 7 \pm 10 \cdot 7)$ and $283 \div 45 \cdot 6 \mu \mathrm{mol} / 1(78 \cdot 3 \div 12 \cdot 6 \mathrm{mg} / \mathrm{l})$.

\section{Alcohol concentrations}

There was no significant difference in the blood alcohol concentration in the three groups when they were tested 25 minutes after the drink of alcohol and 12 hours after a single tablet of chlorpropamide. Mean values for the CPAF-positive, CPAF-negative, and control groups were $1.1 \div 0.26,1.08 \div 0.19,0.91 \div 0.1 \mathrm{mmol} / 1$ respectively $(5 \cdot 1 \pm 1 \cdot 2,5 \cdot 0+0.9$, and $4 \cdot 2 \pm 0.5 \mathrm{mg} / 100 \mathrm{ml})$.

\section{Discussion}

Flushing after alcohol in patients taking chlorpropamide was first reported within a few months of the introduction of chlorpropamide treatment. ${ }^{9}$ Clinically the reaction is obvious to the patient and observer. Because testing with a single tablet of chlorpropamide followed by alcohol ${ }^{2}$ has given varying results, ${ }^{10} 11$ an objective measure of the phenomenon would be useful, and it now seems that the blood acetaldehyde concentration is such a measure. CPAF-positive diabetics showed a greater increase than CPAF-negative diabetics or controls, and although we did not find such a clear separation into two groups as Jerntorp et $a l^{6}$ there was nearly complete division at $6.8 \mu \mathrm{mol}$ $(0.3 \mathrm{mg} / \mathrm{l})$ : after two weeks' chlorpropamide no CPAF-negative subjects exceeded this value whereas all but two of the CPAFpositive cases did so.

Some patients who do not flush at 12 hours after a single dose of chlorpropamide do so after two weeks. Our previous suggestion that a single tablet would be adequate for CPAF testing is thus not always true. To be sure whether a person shows CPAF several days' pre-treatment with chlorpropamide is necessary. This will not convert a non-flusher into a flusher but it will expose all those who flush.
Clinically, CPAF is not the same as simple alcohol flushing. Furthermore, the response of CPAF-positive diahetics to alcohol alone, in terms of increase in temperature and acetaldehyde, is the same as in the CPAF-negative groups. The difference between CPAF-positive and CPAF-negative patients is seen only after chlorpropamide administration and cannot be accounted for by differences in chlorpropamide and alcohol concentrations. Our findings show unequivocally that the pharmacokinetics of chlorpropamide are similar in flushers and non-flushers, both after single doses and during multiple dosing, in contrast to the suggestion of Jerntorp et al. ${ }^{7}$

The concentration of chlorpropamide in blood that will elicit the CPAF response varies: one CPAF-positive diabetic had a rise in facial temperature of $1.5^{\circ} \mathrm{C}$ and an acetaldehyde concentration of $16.3 \mu \mathrm{mol} / \mathrm{l}(0.72 \mathrm{mg} / \mathrm{l})$ with a chlorpropamide concentration of $14.8 \mu \mathrm{mol} / 1(4.1 \mathrm{mg} / \mathrm{l})$ whereas another patient had values of $1.4^{\circ} \mathrm{C}$ and $7.5 \mu \mathrm{mol} / 1(0.33 \mathrm{mg} / \mathrm{l})$ respectively with a plasma chlorpropamide concentration of $76 \cdot 3 \mu \mathrm{mol} / \mathrm{l}(21 \cdot 1$ $\mathrm{mg} / l)$.

Acetaldehyde is formed from alcohol predominantly via the alcohol dehydrogenase pathway and converted to acetate under the control of aldehyde dehydrogenase. Thus its concentration can be influenced by the activity of both these enzymes, which are present in liver and other tissues. One might postulate that CPAF-positive subjects have either increased activity of alcohol dehydrogenase or decreased aldehyde dehydrogenase activity, or both, the second explanation being perhaps the more plausible as chlorpropamide has been shown to inhibit aldehyde dehydrogenase activity in vitro. ${ }^{12}$

It is tempting to speculate that CPAF-positive subjects may have a genetically determined aldehyde dehydrogenase isoenzyme that is particularly susceptible to chlorpropamide inhibition.

We have previously reported that flushers show an increased sensitivity to an analogue of the neuropeptide metenkephalin. ${ }^{4}$ Acetaldehyde has very recently been shown to form adducts with enkephalin. ${ }^{13}$ This raises intriguing possibilities of an interrelationship between the two compounds in the genesis of CPAF.

We thank Mrs L J Blood for performing the alcohol and acetaldehyde assays. AHB is supported by the Medical Research Council.

Requests for reprints should be addressed to Dr D A Pyke, Diabetic Department, King's College Hospital, Denmark Hill, London SE5 9RS.

\section{References}

${ }^{1}$ FitzGerald MG, Gaddie R, Malins JM, O'Sullivan DT. Alcohol sensitivity in diabetics receiving chlorpropamide. Diabetes $1962 ; 11: 40-3$.

${ }^{2}$ Leslie RDG, Pyke DA. Chlorpropamide alcohol flushing: a dominantly inherited trait associated with diabetes. $B r$ Med 7 1978;ii:1519-21.

3 Pyke DA, Leslie RDG. Chlorpropamide alcohol flushing: a definition of its relation to non-insulin dependent diabetes. Br Med f 1978;ii:1521-2.

${ }^{4}$ Leslie RDG, Pyke DA, Stubbs WA. Sensitivity to enkephalin as a cause of non-insulin dependent diabe:es. Lancet 1979;i :341-3.

5 von Wartburg JP, Ris MM. Determination of acetaldehyde in human blood. Experientia $1979 ; 35: 1682-3$

6 Jerntorp P, Öhlin H, Bergström B, Almér LO. Elevation of plasma acetaldehyde-the first metabolic step in CPAF ? Diabetologia 1980;19:286.

' Jerntorp P, Almér LO, Melander A. Is the blood chlropropamide concentration critical in chlorpropamide alcohol flush? Lancet 1981 ; : 165-6.

${ }^{8}$ Prescott LF, Redman DR. Gas-liquid chromatographic estimate of tolbutamide and chlorpropamide in plasma. F Pharm Pharmacol 1972; 24:713-6.

9 Whitelock OVSt, ed. Chlorpropamide and diabetes mellitus. Ann NY Acad Sci 1959;74:407-1028.

10 Köbberling J, Bengsch N, Brüggeboes B, et al. The chlorpropamide alcohol flush. Diabetologia 1980;19:359-63

${ }^{11}$ De Silva NE, Tunbridge WMG, Alberti KGMM. Low incidence of chlorpropamide alcohol flushing in diet-treated non-insulin dependent diabetics. Lancet $1981 ; \mathrm{i}: 128-31$.

12 Podgainy H, Bressler R. Biochemical basis of the sulphonylurea-induced antabuse syndrome. Diabetes $1968 ; 17: 679-83$.

13 Summers MC, Lightmann S. A reaction of acetaldehyde with enkephalins and related peptides. Biochem Pharm (in press). 